$\angle$ Research Square

\section{The impact of Al implementation in higher education on educational process future: A systematic review}

Zouhaier Slimi ( $\nabla$ slimizou@hotmail.com )

University of Deusto: Universidad de Deusto https://orcid.org/0000-0001-8521-2536

\section{Systematic Review}

Keywords: Al, Impact, Higher Education, Assessment, Future Career

Posted Date: November 30th, 2021

DOl: https://doi.org/10.21203/rs.3.rs-1081043/v1

License: (1) (1) This work is licensed under a Creative Commons Attribution 4.0 International License. Read Full License 


\section{Abstract}

Artificial intelligence (Al) has been playing a vital role in all life domains. A striking example is Al effective revolution in health and educational services during the COVID-19 pandemic. Therefore, this systematic literature review investigates how Al impacts higher education (HE) by focusing on its impact on education quality, the learning and teaching process, assessments, and future careers. This review uses a systematic qualitative research method. The data is collected in a systematic review of academic articles on Al impact on HE from 1900 to 2021 from the Web of Science, Scopus, and ERIC. The process went through a systematic inclusion and exclusion procedure based on date, language, reported outcomes, setting and type of publications. Articles selected were screened via Rayyan Software and coded using excel based on the following themes: education quality, learning and teaching, assessments, future careers, and ethics. The total number of articles included is 56 . The results vindicate that Al plays an efficient role in providing better education quality services, practical learning/teaching, and assessments approach for a better future career. Likewise, Al impacts future employment, which entails that HE institutions should incorporate more Al to have better graduates that meet the future market requirements. However, studies on Al impact assessments, ethics and future careers are limited and require further investigation.

\section{Introduction}

We now live in an artificial intelligence era (Al). The impact of artificial intelligence (Al) on education and higher education is a hot issue of discussion and experimentation. $\mathrm{Al}$ is affecting education/higher education, which requires a concise description of skills universities must educate students to prepare them for an Al future of work (Grace Ufuk, 2020). Artificial intelligence has resulted in novel teaching and learning solutions that have been tested in various settings. Apart from its impact on education, Al significantly impacts labour markets, industrial services, agricultural processes, values chains, and the workplace (Kelly, 2021). Al in playing adopting virtual intelligence by most educational systems worldwide and basically by higher institutions during the pandemic (Senel \& Can, 2021).

Current studies indicate that Al is vital in education quality. Equally, Khare and Stewart (2018) believe that Al positively impacts students from a life-cycle perspective using chatbots to support learners and provide better services. Al is also used in auto-grading, constructive feedback, and academic advising (Khare \& Stewart, 2018). A Russian study highlighted educational services perspectives diversifying Al, the fourth revolution, and the social consequences of digitalisation markets. Results revealed that Al stimulates academic and teaching staff reduction. Meanwhile, the economy's digitalisation leads to new education services as entrepreneurship, financially independent institutions, and Al trained staff (Bogoviz et al., 2019).

An analogous Ecuadorian study on how universities gather information about students and predict academic outcomes for proactive curricula, students' attention, and resources management. This study was based on neural networks and Al to parametrise perception. The results revealed the significance of Al in processing the socio-economic data (García-Vélez et al., 2019). Evenly Al was used in the scientific literature in higher education via a study that used Web of Science and Scopus databases from 2007 to 2017 via a bibliometric approach. Results revealed an interest in the subject's literature (Hinojo-Lhavena, Aznar-Díaz, Cáceres-Reche, \& Romero-Rodríguez, 2019). Correspondingly, Muniasamy and Alasiry (2020) argue that deep learning and Al impact e-learning in auto-grading via LMS platforms. The authors applied deep learning in developing e-learning sources and platforms using predictions, algorithms, and analysis. Results revealed that deep understanding plays a significant role in creating platforms and shaping the future of e-learning (Muniasamy \& Alasiry, 2020).

Likewise, Alyahyan and Düştegör (2020) consider students success as institutions' performance matrices. Therefore, they investigated Al's role in predicting at-risk students and taking preventive measures for better performance. Results revealed Al efficiency in mining data, addressing issues and students' needs. Consequently, Al-supported academicians and institutions decide to bring all potentials of success (Alyahyan \& Düştegör, 2020). Equally, Vinichenko, Melnichuk and Karácsony, (2020) studied the most efficient technologies to bridge employee motivation and institutions' incentives using motivational Al. The study investigated academic motives and the university stimulating effect connection. Findings revealed a discrepancy between motivation and stimulation, which has impacted innovation fulfilment. These gaps required applying innovative systems based on Al to meet the digital economy's requirements of the 21 st century. The use of Al improved the staff creative competitiveness and impacted citation index and academic reputation. Al brought advanced solutions to the emerging problems by motivating staff, reducing the imbalance in staff motives and university incentives, and increasing staff publication and grants (Vinichenko et al., 2020).

Finally, Al and robotics are having a long-term impact on HE. These impacts are technical and pedagogical as well as social (Cox, 2021). Equally, Moridis and Economides (2009) combined various evidence on online assessment interference. A formula-based method was implemented in three European regions to predict 153 students' moods via data emanated experiments. Findings vindicated to a high level the assumptions of the formula-based method about students' moods. Evenly, results showed that algorithms and neural networks should complement each other for better recognition mechanisms. Equivalently, neural networks can replace tutoring systems that affect recognition methods (Moridis \& Economides, 2009).

The taxonomy expanded upon D'Mello and Graesser (2015) dichotomy of emotion-aware systems to guide a system that can foster positive emotions along the learning process via different approaches, design features and data sources. Comparably, Kaplan and Haenlein (2019) define Al as the system's ability to interpret, learn and apply data to achieve defined goals and tasks via a flexible application. The study analysed how Al differs from the internet of things and big data. Thus, it suggested looking at Al via evolutionary stages such as narrow and general Al or focusing on other systems such as human-inspired and humanised scholars. Results presented a framework that helps an organisation consider Al's internal and external implications in three labels C-model: confidence, change and control (Kaplan \& Haenlein, 2019).

Consonantly, Tashfeen (2019) explored how policymakers see education future within the continuing technology disruption. Thus, two learning alternatives were developed a vignette approach of the emerging technologies and space scenarios framework. Findings revealed that future scenarios involving 
cooperative styles like human machines cooperation and active virtual learning produce more desirable benefits for education stakeholders. Implementing Al, $5 \mathrm{G}$ and automation will customise HE delivery and work landscape (Tashfeen, 2019).

Online learning increases demand, artificially intelligent teaching, machine learning, and teaching assistants experimented with Al teaching assistance in the USA without knowing how learners perceive Al assistants. Findings indicated Al teaching assistant efficiency, communication ease, and Al teaching assistant's eventual adoption. The researchers recommend using teacher assistants and further investigations to understand better the nuances of Al teaching assistants' learning and teaching (Kim, Merrill, Xu, \& Sellnow, 2020).

Moreover, Xiao and Yi (2020) investigated Al's efficiency in HE teaching and education's remarkable regularity of individual subjects. The study suggested personalised education that considers learners' desires and societal development needs. Evenly affirm the inefficiency of traditional teaching methods in fulfilling individualised learning. Therefore, Al is the best alternative to achieving personalised learning via data analysis and modelling methods. Thus, Al predicts and tracks students' performance based on individualised training (Xiao \& Yi, 2020).

GNS, Sanjinis and Nardo (2012) developed Al fuzzy logic assessment methods and competencies using Bolivia's subjective and objective tutor and tutee features. Findings indicate the method's usefulness at all education levels (GNS et al., 2012). Comparably, Camps et al. (2016) argue that HE activities humanlike system applications of knowledge to analyse academic credits and validate them for students from other institutions. Thus, an Al system was created to validate higher institutions' academic credits. The approach followed elicitation, modelling and construction of knowledge base. The findings indicate that the system achieved the goal and acted as an efficient tool validating academic credits analysis to a level of 89.4\% (Campos et al., 2016).

Likewise, Radović, Petrović and Tošić (2020) highlighted the requirements of an efficient curriculum along with an improved and renewed assessment method. The Comprehensive Integrative Puzzle (CIP) is one of the promising emerging practices. However, it requires high efforts, a team of experts, a native representative of the English language, and a time-consuming approach that presents an automatic generation of CIP assessments questions. Findings indicate that the adoption of ontological knowledge representation enables multilingual education domains. Medical education automation is one of the most challenging fields in the CIP. However, automation promises innovative teaching methods in all educational domains (Radović et al., 2020).

Correspondingly, sustainable Al requires ethical governance in increasing worldwide demand. China has enhanced Al technologies and published Al ethical guidelines and principles to benefit societies, companies, states, and research organisations by stressing: privacy, security, safety, reliability, accountability, transparency, and fairness. Equally, the Economic countries released Al ethical guidelines and governance regulations. In 2018, the EU announced the General Data Protection Regulation (GDPR). Equally, the White House issued Al executive order to maintain American leadership. The National Institute of Standards and Technology developed technical regulations for reliable, robust and trustworthy Al systems. Equivalently, the United Nations promised to promote Al ethics and called for an Al conference in 2019 stressing Al links with human values. Finally, Google, Amazon, Microsoft, Alibaba, Baidu and Tencent got involved in Al ethics and governance (Bozkurt et al., 2021).

Al is vital in knowledge management, learning, teaching and skills development. Thus, Al is needed along with human skills as it is a requirement of the future workforce. Automation and the gig economy radically change job descriptions and work methods, making human and Al skills, adaptability, and resourcefulness key to success (Taneri, 2020). Gong et al. (2019) highlighted the potential of Al in transforming radiology and clinical practices. The study targeted Canadian medical students and their perception of Al's influence on their radiology majors' performance. Findings revealed that most $67.7 \%$ disagree that Al would replace radiologists, in contrast with a minority of $(29.3 \%)$ who agreed that Al would replace radiologists in the future. Additionally, $48.6 \%$ were anxious considering Al in radiology. The radiology community was interested in expert opinions on Al and suggested that medical students educate about Al's possible impact on radiology (Gong et al., 2019a).

Likewise, Llorente (2020) stresses the various revolutions from engine steam to electricity and assembly lines, moving to the computer in 1960 and the fourth revolution. The fourth revolution involves Al, digital technology, globalisation and hyperconnectivity (G5). This revolution requires radical lifestyle changes and the workplace. The social labour situation faces significant difficulties such as increasing unemployment, the ageing society, the emergence of new leading sectors in the job market, exponential technology development, the excessive use of robotisation and globalisation of the market. Consequently, radical changes require new educational systems, companies and work organisations. Results indicate automation will increase productivity, devalue salaries and eradicate tasks. E-workers will have different ambitions than the current ones. The concept of jobs will be replaced by career professionalism. The big corporate economy will replace the current one (Llorente, 2020). Finally, this systematic review investigates how artificial intelligence affects higher education and studies the impacts of Al on education quality, the learning and teaching process and future careers.

\section{Methodology}

This review is a rigorous approach synthesising and amalgamating the most recent academic papers on Al's impact on HE since 121 years. The research question was formulated based on PICOT (patient/population; intervention/indicator, compare/control; outcome; and time/type of study or question) focusing on prognosis/prediction question: Does Al implementation in higher education impact the educational process in the future? The final search equation was defined using the Boolean connector "AND", and the keyword combinations were made, ensuring one keyword for each search category (Artificial intelligence, impact, higher education). The review followed the PRISMA checklist for a systematic review, ensuring transparency and entirely reporting metanalysis and systematic review (Liberati et al., 2009). The review also used a systematic qualitative method to systematically search for evidence from primary qualitative studies and draw the findings (Seers, 2015).

The preliminary process started with titles processing. Suppose the title is related to the scope of Al and HE. In that case, the article is selected and exported to Rayyan Software, including author, year, title and abstract for further screening. Data collected is secondary via desk research focusing only on academic articles relevant to the abovementioned topic and processed via the reference management App Mendeley. The limited researcher investigation to the Web of

Page $3 / 10$ 
Science, Scopus, and ERIC across various disciplines ensures reliability and validity. The researcher created a research protocol made of five features: (1) date, (2) language, (3) reported outcomes, (4) setting and (5) type of publication. The protocol used transparent criteria of inclusion and exclusion to shortlist articles researched. The researcher screened articles via Rayyan Software. The protocol was to minimise bias, ensure transparency, replicability, and as an indicator of feasibility (Choi et al., 2019).

\section{Eligibility assessment}

To ensure the adequacy of screening, the researcher used Rayyan Software, a free mobile and web app for systematic literature review provided by the University of Qatar. A total of 509 articles was found in the first stage and exported via Endnote for screening following the designed inclusion/exclusion criteria. Therefore, the total number of included articles is 56 from Scopus, Web of Science and ERIC. The researcher thematically coded the articles via Excel. Consequently, four major areas were highlighted, education quality, learning and teaching, assessment, future career, and Al ethics in higher education. (For further details, see figure 1)

\section{Inclusion and exclusion criteria}

The article's inclusion used the following criteria: 1900 to 2021, language limited to English only, and publication types were limited to academic articles. The setting was only linked to higher education institutions and Al. The review also was limited to only consistent, appropriate outcomes (The University of Melbourne, 2021). Overall, the study's scope focused on Human Science and disciplines like Computer Science. The exclusion criteria were as follows: exclude sources not written between 1900 and 2021, sources written in other languages than English, sources with inconsistent outcomes, sources not linked to higher education.

\section{Findings}

The final selection included 56 scientific articles that provided evidence regarding the educational quality, Learning and teaching, and Al ethics in higher education and Future Careers in Higher education. Table 1 summarises the information on the articles: reference, country, sample, research design, Key findings.

Table 1: Summary of significant findings 


\begin{tabular}{|c|c|c|c|c|}
\hline References & Country & Sample & Research design & Key findings \\
\hline \multicolumn{5}{|c|}{ Impact on the Educational quality } \\
\hline $\begin{array}{l}\text { (Assiri et } \\
\text { al., 2020) }\end{array}$ & $\begin{array}{l}\text { Saudi } \\
\text { Arabia }\end{array}$ & Articles and conferences 2009-2019 (e-academic advising) & $\begin{array}{l}\text { Systematic } \\
\text { literature review }\end{array}$ & $\begin{array}{l}\text { The application of AI is both practical and efficient. Adopting a multitasking system necessitates the } \\
\text { develop ground-breaking academic advice systems. }\end{array}$ \\
\hline $\begin{array}{l}\text { (Bañeres et } \\
\text { al., 2020) }\end{array}$ & Spain & 2 undergraduate courses in 6 semesters & $\begin{array}{l}\text { Experimental } \\
\text { research }\end{array}$ & AI provides early warnings to help stakeholders and at-risk situations. When it comes to spotting at-ri \\
\hline $\begin{array}{l}\text { (Bojorque \& } \\
\text { Pesántez- } \\
\text { Avilés, } \\
2020)\end{array}$ & $\begin{array}{l}\text { Latin } \\
\text { America }\end{array}$ & $\begin{array}{l}\text { Information about syllabus, grades, assessments, and online content from a } \\
\text { Latin American University }\end{array}$ & $\begin{array}{l}\text { Experimental } \\
\text { research }\end{array}$ & AI enhances individualized learning and helps to design e-learning platforms. \\
\hline $\begin{array}{l}\text { (Bogoviz et } \\
\text { al., 2019) }\end{array}$ & Russia & Academic years 2000/2001-2018/2019. & $\begin{array}{l}\text { Forecasting } \\
\text { method }\end{array}$ & AI minimizes academic staff, expands educational services, and ensures financial independence. \\
\hline $\begin{array}{l}\text { (Breaux, } \\
\text { 2017). }\end{array}$ & U SA & 2 scenarios & $\begin{array}{l}\text { "Framework } \\
\text { Foresight" method }\end{array}$ & AI enables students to communicate more effectively and to feel more connected to the rest of the wor \\
\hline $\begin{array}{l}\text { (Chen et al., } \\
2020)\end{array}$ & China & 30 articles & Systematic review & Artificial intelligence helps with decision-making, adaptability, cognitive capacities, grading, feedbacl \\
\hline$($ Cox, 2021) & UK & 200 fictions & Systematic review & $\begin{array}{l}\text { AI sparks a broader debate by posing questions such as how it might be used to teach higher-order sl } \\
\text { the nature of datafication. }\end{array}$ \\
\hline $\begin{array}{l}\text { (Fayoumi \& } \\
\text { Hajjar, } \\
2020)\end{array}$ & $\begin{array}{l}\text { Saudi } \\
\text { Arabia }\end{array}$ & A large volume of data & $\begin{array}{l}\text { Experimental } \\
\text { method }\end{array}$ & AI enables quality assurance of planning, academic advising and monitoring the educational decisions \\
\hline $\begin{array}{l}\text { ((Korepin et } \\
\text { al., 2020) }\end{array}$ & Russia & 1600 respondents aged $18-54$ & $\begin{array}{l}\text { Experimental } \\
\text { method }\end{array}$ & $\begin{array}{l}\text { AI enhances Problem-solving, creativity, and time management. Higher education institutions' essent } \\
\text { big data, and the internet. }\end{array}$ \\
\hline $\begin{array}{l}\text { (Limani et } \\
\text { al., 2019) }\end{array}$ & Kosovo & 168 respondents & Qualitative method & AI, the internet of things, and cloud computing are the most critical digital transformation technologi \\
\hline $\begin{array}{l}\text { (Bogoviz et } \\
\text { al., 2019) }\end{array}$ & Russia & 1000 students \& academic staff & $\begin{array}{l}\text { Forecasting } \\
\text { method }\end{array}$ & AI reduces academic staff, brings new education services such as entrepreneurship and establishes ir \\
\hline $\begin{array}{l}\text { (Prinsloo, } \\
2020)\end{array}$ & $\begin{array}{l}\text { South } \\
\text { Africa }\end{array}$ & $\begin{array}{l}\text { Black Box Society. } \\
\text { list of articles here: } \\
\text { https://journals.sagepub.com/page/bds/collections/revisitingtheblackb oxsociety }\end{array}$ & $\begin{array}{l}\text { Experimental } \\
\text { method }\end{array}$ & $\begin{array}{l}\text { AI aids strategic planning and successful learning and teaching. As a result, AI provides timely, acces } \\
\text { intervention. }\end{array}$ \\
\hline $\begin{array}{l}\text { (Sekeroglu } \\
\text { et al., 2019) }\end{array}$ & Portugal & $\begin{array}{l}1,044 \\
\text { Students }\end{array}$ & $\begin{array}{l}\text { Experimental } \\
\text { method }\end{array}$ & AI enhances individualized learning and helps to design e-learning platforms. \\
\hline $\begin{array}{l}\text { (Tamla et } \\
\text { al., 2019) }\end{array}$ & Germany & 23.046 final thesis titles (1999-2016) & Statistical method: & AI, the internet of things, and Cloud technologies are promising in developing and innovating HE cur \\
\hline $\begin{array}{l}\text { (Tsai et al., } \\
2020)\end{array}$ & Taiwan & 3552 students & $\begin{array}{l}\text { Experimental } \\
\text { method }\end{array}$ & With a rate of 68 to 77 per cent, AI accuracy forecasted if students would drop out. \\
\hline $\begin{array}{l}\text { (Alyahyan \& } \\
\text { Düştegör, } \\
\text { 2020) }\end{array}$ & Turkey & Articles from 2015-2020 & Systematic review & AI helps predict-risk students and efficiently perform data mining. \\
\hline $\begin{array}{l}\text { (Yakubu et } \\
\text { al., 2020) }\end{array}$ & Nigeria & 1116 students & $\begin{array}{l}\text { Experimental } \\
\text { method: }\end{array}$ & AI develops LMS systems and predicts the learner needs. \\
\hline \multicolumn{5}{|c|}{ Impact on the learning and teaching process } \\
\hline $\begin{array}{l}\text { (Aparicio et } \\
\text { al., 2018) }\end{array}$ & Spain & 11 professors & Mixed-methods & AI boosts active and executive learning, which enhances the learning quality. \\
\hline $\begin{array}{l}\text { (Bhalla, } \\
\text { 2019) }\end{array}$ & Uk & 153 students & Case study & AI integrates empathy via thinking to reduce bias, provide feedback, input, and solutions. \\
\hline $\begin{array}{l}\text { (CY \& } \\
\text { Chunyan, } \\
2017)\end{array}$ & Sing apore & Not given & $\begin{array}{l}\text { Experimental } \\
\text { method }\end{array}$ & AI developed language teaching skills and revealed an English teaching efficiency. \\
\hline $\begin{array}{l}\text { (Fan et al., } \\
2020 \text { ) }\end{array}$ & China & 6 projects & $\begin{array}{l}\text { Experimental: } \\
\text { Brain-imaging } \\
\text { technology }\end{array}$ & AI helps to map the brain at multiple scales and explore how neural activity patterns transform into $\mathrm{c}$ \\
\hline $\begin{array}{l}\text { (Gamez, } \\
\text { 2019) }\end{array}$ & UK & 200 students & $\begin{array}{l}\text { Experimental } \\
\text { method }\end{array}$ & AI via neuro-lecturing measures students cognitive learning process and reacts timely, providing cons \\
\hline $\begin{array}{l}\text { (Harley et } \\
\text { al., 2017) }\end{array}$ & Canada & 3 Universities & Empirical method & AI helps develop emotional awareness for an efficient learning process. \\
\hline $\begin{array}{l}\text { (Kaplan \& } \\
\text { Haenlein, } \\
\text { 2019) }\end{array}$ & USA & Series of case studies & Case study & AI entails three C-model to confidence, change, and control. Therefore, it enhances learning and teach \\
\hline $\begin{array}{l}\text { (Loftus \& } \\
\text { Madden, } \\
\text { 2020). }\end{array}$ & USA & Not given & $\begin{array}{l}\text { Experimental } \\
\text { method via } \\
\text { Bayesian Networks }\end{array}$ & $\begin{array}{l}\text { AI connects brain programs and investigates neuroscience experiments for subversive working model: } \\
\text { perception. }\end{array}$ \\
\hline $\begin{array}{l}\text { (Moridis \& } \\
\text { Economides, } \\
\text { 2009) }\end{array}$ & Macedonia & 153 students & $\begin{array}{l}\text { Experimental } \\
\text { method }\end{array}$ & Algorithm and neutral works are helpful for mechanisms and efficient tutoring. \\
\hline $\begin{array}{l}\text { (Ocaña- } \\
\text { Fernandez } \\
\text { et al., 2019) }\end{array}$ & Peru & 543 Purposes and Representations & Experimental study & Universities face a significant problem in developing, designing, and implementing digital skills and ] \\
\hline $\begin{array}{l}\text { Olusoji Ilori } \\
\text { and } \\
\text { Ajagunna } \\
(2020)\end{array}$ & Nigeria & 7 case studies & $\begin{array}{l}\text { Desk } \\
\text { research method }\end{array}$ & $\begin{array}{l}\text { AI has a significant impact on how people learn. } \\
\text { Educational institutions will serve as incubators for AI-based innovation. }\end{array}$ \\
\hline $\begin{array}{l}\text { (Tashfeen, } \\
\text { 2019) }\end{array}$ & Jamaica & Review of 6 surveys & Case study & $5 \mathrm{G}$ and automation customise and personalise higher education for better productivity and quality. \\
\hline $\begin{array}{l}\text { (W. H. Kim } \\
\text { \& Kim, } \\
\text { 2020). }\end{array}$ & $\begin{array}{l}\text { South } \\
\text { Korea }\end{array}$ & $\begin{array}{l}800,000 \text { training sets were collected from a commercialized mobile application } \\
\text { teaching the Korean language. }\end{array}$ & $\begin{array}{l}\text { Experimental } \\
\text { method }\end{array}$ & AI creates novel learning channels by adopting reasoning learning theories via in-depth networks. \\
\hline $\begin{array}{l}\text { (Waghid et } \\
\text { al., 2019) }\end{array}$ & $\begin{array}{l}\text { South } \\
\text { Africa }\end{array}$ & Universities in South Africa (Number not given) & $\begin{array}{l}\text { Experimental } \\
\text { method }\end{array}$ & Incorporating artificial intelligence (AI) into all higher education institutions prepares students for th \\
\hline $\begin{array}{l}\text { (Williams, } \\
\text { 1992) }\end{array}$ & England & 10 projects & Case study & AI is vital for higher education as it prepares the learner for future life. \\
\hline $\begin{array}{l}\text { (Xu and Yu, } \\
2020 \text { ). }\end{array}$ & China & 150 articles & Systematic review & AI creates a motivating relationship between robots and students for higher learning through practice \\
\hline $\begin{array}{l}\text { (Yang et al., } \\
2020 \text { ) }\end{array}$ & China & Chongqing Three Gorges College students & $\begin{array}{l}\text { Experimental } \\
\text { method }\end{array}$ & AI tailors teaching methods according to job requirements collaboratively. \\
\hline
\end{tabular}




\begin{tabular}{|c|c|c|c|c|}
\hline $\begin{array}{l}\text { (Zapata-Ros, } \\
\text { 2018). }\end{array}$ & Spain & 5 educational theoretical approaches & $\begin{array}{l}\text { Experimental } \\
\text { method }\end{array}$ & AI develops personal and group skills efficiently and adequately \\
\hline $\begin{array}{l}\text { (Zawacki- } \\
\text { Richter et } \\
\text { al., 2019) }\end{array}$ & Germany & 146 articles & Systematic review. & AI improves administrative services, prediction/profiling, assessment, personalised adaptive systems \\
\hline \multicolumn{5}{|c|}{ Impact on assessments } \\
\hline $\begin{array}{l}\text { (GNS et al., } \\
2012 \text { ) }\end{array}$ & Bolivia & Educational institutions in Bolivia 2012 & $\begin{array}{l}\text { Experimental } \\
\text { method }\end{array}$ & $\mathrm{AI}$ impacts $\mathrm{HE}$ assessments at various levels. \\
\hline $\begin{array}{l}\text { (Campos et } \\
\text { al., 2016) }\end{array}$ & Brazil & 2 users & $\begin{array}{l}\text { Experimental } \\
\text { method }\end{array}$ & $\mathrm{AI}$ is efficient in validating academic credits by a level of $89.4 \%$. \\
\hline $\begin{array}{l}\text { (Deo et al., } \\
2020 \text { ). }\end{array}$ & Australia & 4200 students & $\begin{array}{l}\text { Experimental } \\
\text { method }\end{array}$ & AI is efficient in analysing assessments variables and reinforcing intervention for better graduate attri \\
\hline \multicolumn{5}{|c|}{ Ethics and Future Careers in higher education } \\
\hline $\begin{array}{l}\text { Clifton et al. } \\
(2020)\end{array}$ & UK & 100 reports and studies & Empirical method & AI will revolutionize the workplace. It is tough to say how much AI will threaten jobs. \\
\hline $\begin{array}{l}\text { (García- } \\
\text { Peñalvo et } \\
\text { al., 2018) }\end{array}$ & Spain & 3000 students & A case study & AI helps predict learners' future careers. \\
\hline $\begin{array}{l}\text { (Gong et al., } \\
\text { 2019b) }\end{array}$ & Canada & 17 medical schools & $\begin{array}{l}\text { Quantitative } \\
\text { method }\end{array}$ & (67.7\%) think that AI reduces the need for radiologists, whereas (29.3\%) believe that AI will eventua \\
\hline $\begin{array}{l}\text { (Pana, } \\
\text { 2006) }\end{array}$ & Romania & 9 intelligent agents & $\begin{array}{l}\text { Experimental } \\
\text { method }\end{array}$ & Machine ethics can/will be of incredible quality because it will be developed from technical research a \\
\hline $\begin{array}{l}\text { (Wu et al., } \\
2020 \text { ) }\end{array}$ & China & $\begin{array}{l}\text { Ethical guidelines and AI principles } \\
\text { in China }\end{array}$ & Quantitative study & Ethics and values must guide AI to ensure that it is helpful to societies, businesses, institutions, and \\
\hline $\begin{array}{l}\text { (Ylldırım \& } \\
\text { Yildız, } \\
\text { 2018) }\end{array}$ & Turkey & More than a million articles & $\begin{array}{l}\text { Experimental } \\
\text { method }\end{array}$ & $\mathrm{AI}$ and robotics will impact some professions, such as librarianship and radiology \\
\hline
\end{tabular}

Findings address four crucial topics as summarised in the above table (1) Impact on the Education quality, (2) Impact on the learning and teaching process, and (3) Impact on assessments, and (4) Impact on ethics and future careers in higher education. The following part is a deep analysis of the significant results found.

\section{Impact on the Education quality}

Findings indicate that Al transforms education quality: Al helps learners communicate better and connect to the world (Breaux, 2017). The internet of things, Cloud technologies and Al, are promising in developing and innovating HE curricula (Tamla et al., 2019; Limani et al., 2019). Al reduces academic staff and brings new education services such as entrepreneurship and Al training for financially independent institutions (Ogoviz et al., 2019). Besides, Al improves personalised education and develops e-learning platforms (Sekeroglu et al., 2019). Al develops LMS systems and predicts the learner needs (Yakubu et al., 2020). Likewise, Al processes structured and unstructured data to reduce management workload and speeds decision-making (Bojorque \& Pesántez-Avilés, 2020). Equally, Al enhances problem-solving, creativity, time management and communication (Korepin et al., 2020). Al reinforces strategic planning and effective learning and teaching. Therefore, Al provides speedy, accessible data and intelligent analysis that leads to proper intervention at the right time (Prinsloo, 2020). Al boosts cognitive abilities, learning adaptability and timely decision making. Al enables instructors to take multiple actions simultaneously: grading, giving feedback and detecting at-risk students (Chen et al., 2020). Constantly, Al helps predict-risk students and efficiently perform data mining (Yahyan and Düştegör, 2020). Therefore, (Fayoumi and Hajjar, 2020; Tsai et al., 2020; Assiri, Al-Ghamdi and Brdesee, 2020 and Bañeres et al., 2020) (the educationally advanced visualisation and early interventions. Briefly, Al improves creative teaching, impacts HE institutions' academic reputation and citation index, prepares learners for future life (Vinichenko et al., 2020).

\section{Impact on the learning and teaching process}

Results revealed a vital need for Al in teaching and learning (Williams, 1992). Moridis and Economides (2009) recommended using algorithms and neutral works for better recognition mechanisms and efficient tutoring. Likewise, Harley et al. (2017) found that Al helps develop emotional awareness for efficient learning. Equally, Al developed language teaching skills and revealed an English teaching efficiency (CY \& Chunyan, 2017). Results show that Al boosts active and executive learning (Aparicio et al., 2018). Similarly, findings vindicate that Al develops personal and group skills efficiently and adequately (Zapata-Ros, 2018).

Additionally, according to Kaplan and Haenlein (2019), Al entails three C-models: confidence, change, and control. Therefore, it enhances learning and teaching efficiency. Besides, Al via neuro-lecturing measures students cognitive learning process and reacts timely, providing constructive feedback (Gamez, 2019). Alike (Waghid, Waghid and Waghid, 2019; Ocaña-Fernandez, Valenzuela-Fernandez and Garro-Aburto, 2019) found that Al integration into all higher institutions prepares learners for their future careers. Similarly, Tashfeen (2021) found that $5 \mathrm{G}$ and automation customise and personalise HE. While Bhalla (2019) insists that Al integrates empathy via thinking to reduce bias, provide feedback, input, and solutions.

Furthermore, findings justify that Al efficiently enhances four domains: admin services, prediction and profiling, assessment and personalised adaptive systems, equally intelligent tutoring (Zawacki-Richter et al., 2019). Meanwhile, Al collaboratively tailors teaching methods according to job requirements (Yang et al., 2020). Consonantly, Al supports students and teachers to work together in a praxis approach to explore the world around them (Loftus \& Madden, 2020). Analogously, Al connects bran programs and investigates neuroscience experiments for subversive working models applying machine thinking, decisionmaking, and perception (Fan et al., 2020). Equivalently, Al creates a motivational relationship between robots and students for better learning through practical design and interactive reactions and teacher assistants (Xu and $\mathrm{Yu}, 2020)$. Al creates novel learning channels by adopting reasoning learning theories via in-

Page $6 / 10$ 
depth networks (W. H. Kim \& Kim, 2020). Finally, findings indicate the need for a dynamic, rapid learning and teaching process parallel with technological and digital advances (Olusoji llori \& Ajagunna, 2020).

\section{Impact on assessments}

Al impacts HE assessments by revealing the importance of Al in assessments and at different levels (GNS et al., 2012). Camps et al. (2016) concludes that Al is efficient in validating academic credits by a level of $89.4 \%$. Evenly, outcomes vindicate that Al has proven its efficiency in analysing assessments variables and reinforcing intervention for better graduate attributes (Deo et al., 2020). Finally, results pinpoint that Al enables multilingual domains and generates comprehensive, interactive assessments.

\section{Impact on Ethics and Future Careers in higher education}

Results reveal a crucial need for moral systems. Therefore, efficient technical, theoretical and psychological supplements must reinforce Al with spirit and conscience (Pana, 2006). Additionally, Al must be guided by ethics and principles to ensure that it is beneficial for societies, companies, institutions and humans worldwide (Wu et al., 2020). Concerning future careers, findings indicate that Al and robotics will impact some professions, such as librarianship and radiology (Yildirim and Yildiz, 2018; Gong et al., 2018). Besides, results stressed that Al helps predict learners' future careers (García-Peñalvo et al., 2018). Finally, it is needed to explore the rapid transformation of the quality and quantity of work socially, geographically, and at a governmental level (Clifton et al., 2020).

\section{Conclusions}

This literature review focused on the influence of artificial intelligence on higher education. The impact of artificial intelligence (Al) on education and higher education is becoming a burning issue worth experimentation as Al is affecting life and education/higher education. The literature reviewed has covered four major areas: the impact of Al on educational quality, learning and teaching process, assessment, and ethics and future careers. The existing literature highlights the importance of $\mathrm{Al}$ in higher education and insists on implementing Al in the educational system and training academic staff and learners with Al for better educational systems and a better future. The significant gaps found are that studies conducted are about Al and higher education in general and do not focus on particular areas in education such as learning, teaching, assessment, and quality to assist the learner and tutor more. Most of the studies conducted are based on experimental methods. Lack of studies related to the use of Al in assessment, ethics and future careers of learners. This literature review tried to cover these gaps and findings vindicate the vital role of $\mathrm{Al}$ in transforming higher education services, quality, teaching, learning methods. The review indicates the importance of Al in education quality which meets with the findings of (Radović et al., 2020; Camps et al. 2016; GNS et al., 2012; and Grace Ufuk, 2020). Al helps create engaging learning methods, which agrees with the findings of (Xiao \& Yi, 2020; Kelly, 2021; Senel \& Can, 2021; Khare \& Stewart, 2018; and Bogoviz et al., 2019). Al assists in moulding higher institutions that can deal with big data, retain students, prepare the learner for the future job market, providing the proper skills required by the fourth revolution, which goes hand in hand with the results found by (Muniasamy \& Alasiry, 2020; (Alyahyan and Düştegör, 2020; Vinichenko et al., 2020; and Tashfeen, 2019). Finally, it is recommended that further investigation prioritise the impact of Al use on the learners' assessments and the ethical impacts on education and future careers.

\section{Declarations}

Availability of data and materials

https://rayyan.ai/reviews

Funding:

Not applicable

\section{References}

1. Alyahyan, E., \& Düştegör, D. (2020). Predicting academic success in higher education: literature review and best practices.Springer Open. https://doi.org/10.1186/s41239-020-0177-7

2. Aparicio, F., Morales-Botello, M. L., Rubio, M., Hernando, A., Muñoz, R., López-Fernández, H. ... de Buenaga, M. (2018). Perceptions of the use of intelligent information access systems in university level active learning activities among teachers of biomedical subjects. International Journal of Medical Informatics, 112, 21-33

3. Assiri, A., Al-Ghamdi, A. A. M., \& Brdesee, H. (2020). From traditional to intelligent academic advising: A systematic literature review of e-academic advising. International Journal of Advanced Computer Science and Applications, 11(4), 507-517

4. Bañeres, D., Rodríguez, M. E., Guerrero-Roldán, A. E., \& Karadeniz, A. (2020). An early warning system to detect at-risk students in online higher education.Applied Sciences (Switzerland), 10(13). https://doi.org/10.3390/app10134427

5. Bhalla, N. (2019). The 3S process: A framework for teaching Al strategy in business education. Technology Innovation Management Review, 9(12), 36-42

6. Bogoviz, A. V., Lobova, S. V., Karp, M. V., Vologdin, E. V., \& Alekseev, A. N. (2019). Diversification of educational services in the conditions of industry 4.0 on the basis of Al training. On the Horizon, 27(3-4), 206-212 
7. Bojorque, R., \& Pesántez-Avilés, F. (2020). Academic Quality Management System Audit Using Artificial Intelligence Techniques. Advances in Intelligent Systems and Computing, 965, 275-283

8. Bozkurt, A., Karadeniz, A., Baneres, D., Guerrero-Roldán, A. E., \& Rodríguez, M. E. (2021). Artificial intelligence and reflections from educational landscape: A review of Al studies in half a century. Sustainability (Switzerland), 13(2), 1-16

9. Breaux, J. (2017). The future of student life: connecting. On the Horizon, 25(3), 173-176

10. Campos, F. H., Montanha, G. K., Andrade, V. C., \& Benito, F. C. V. (2016). Expert system for validation of academic credits in higher education institutions. IEEE Latin America Transactions, 14(9), 4136-4142

11. Chen, L., Chen, P., \& Lin, Z. (2020). Artificial Intelligence in Education: A Review. IEEE Access, 8, 75264-75278

12. Choi, A. R., Cheng, D. L., \& Greenberg, P. B. (2019). Twelve tips for medical students to conduct a systematic review. Medical Teacher, $41(4), 471-475$

13. Clifton, J., Clifton, J., Glasmeier, A., \& Gray, M. (2020). When machines think for us: The consequences for work and place. Cambridge Journal of Regions, Economy and Society, 13(1), 3-23

14. Cox, A. M. (2021). Exploring the impact of Artificial Intelligence and robots on higher education through literature-based design fiction.International Journal of Educational Technology in Higher Education, 18(1). https://doi.org/10.1186/s41239-020-00237-8

15. CY, X., \& Chunyan, X. (2017). English assistant teaching system of higher vocational education based on expert system. https://www.researchgate.net/publication/319091331_English_assistant_teaching_system_of_higher_vocational_education_based_on_expert_system

16. Deo, R. C., Yaseen, Z. M., Al-Ansari, N., Nguyen-Huy, T., Langlands, T. A. M. P., \& Galligan, L. (2020). Modern Artificial Intelligence Model Development for Undergraduate Student Performance Prediction: An Investigation on Engineering Mathematics Courses. IEEE Access, 8, 136697-136724

17. Fan, J., Fang, L., Wu, J., Guo, Y., \& Dai, Q. (2020). From Brain Science to Artificial Intelligence.. In Engineering (6 vol., pp. 248-252). Elsevier Ltd

18. Fayoumi, A. G., \& Hajjar, A. F. (2020). Advanced learning analytics in academic education: Academic performance forecasting based on an artificial neural network. International Journal on Semantic Web and Information Systems, 16(3), 70-87

19. Gamez, D. (2019). Could neurolecturing address the limitations of live and recorded lectures? - Middlesex University Research Repository. https://eprints.mdx.ac.uk/23819/

20. García-Peñalvo, F., Cruz-Benito, J., Martín-González, M., Vázquez-Ingelmo, A., Sánchez-Prieto, J. C., \& Therón, R. (2018). Proposing a Machine Learning Approach to Analyze and Predict Employment and its Factors. International Journal of Interactive Multimedia and Artificial Intelligence, 5(2), 39

21. García-Vélez, A., López-Nores, R., González-Fernández, M., Robles-Bykbaev, G., Espartaco, V., Manolis, W. ... Gil-Solla, A. (2019). On Data Protection Regulations, Big Data and Sledgehammers in Higher Education. APPLIED SCIENCES-BASEL. https://doi.org/10.3390/app9153084

22. GNS, T., Sanjinis, T., \& Nardo, G. (2012). (13) (PDF) Methodology and tool for the evaluation of the students in the different institutions of education. CLIO AMERICA.

https://www.researchgate.net/publication/313240746_Methodology_and_tool_for_the_evaluation_of_the_students_in_the_different_institutions_of_educa

23. Gong, B., Nugent, J. P., Guest, W., Parker, W., Chang, P. J., Khosa, F., \& Nicolaou, S. (2019a). Influence of Artificial Intelligence on Canadian Medical Students' Preference for Radiology Specialty: ANational Survey Study. Academic Radiology, 26(4), 566-577

24. Gong, B., Nugent, J. P., Guest, W., Parker, W., Chang, P. J., Khosa, F., \& Nicolaou, S. (2019b). Influence of Artificial Intelligence on Canadian Medical Students' Preference for Radiology Specialty: ANational Survey Study. Academic Radiology, 26(4), 566-577

25. Grace Ufuk, T. (2020). Artificial Intelligence \& Higher Education: Towards Customized Teaching and Learning, and Skills for an Al World of Work. Research \& Occasional Paper Series: CSHE.6.2020. Center for Studies in Higher Education

26. Harley, J. M., Lajoie, S. P., Frasson, C., \& Hall, N. C. (2017). Developing Emotion-Aware, Advanced Learning Technologies: A Taxonomy of Approaches and Features. International Journal of Artificial Intelligence in Education, 27(2), 268-297

27. Hinojo-Lucena, F. J., Aznar-Díaz, I., Cáceres-Reche, M. P., \& Romero-Rodríguez, J. M. (2019). Artificial intelligence in higher education: A bibliometric study on its impact in the scientific literature.Education Sciences, 9(1). https://doi.org/10.3390/educsci9010051

28. Kaplan, A., \& Haenlein, M. (2019). Siri, Siri, in my hand: Who's the fairest in the land? On the interpretations, illustrations, and implications of artificial intelligence.. In Business Horizons (62 vol., pp. 15-25). Elsevier Ltd1

29. Kelly, S. (2021). ERIC - ED612439 - Understanding the Impact of Artificial Intelligence on Skills Development. Education 2030, UNESCO-UNEVOC International Centre for Technical and Vocational Education and Training, 2021. https://eric.ed.gov/?

q=\%22artificial+intelligence\%22+impact+\%22higher+education\%22+2021\&id=ED 612439

30. Khare, K., \& Stewart, B. (2018). Artificial Intelligence and the Student Experience: An Institutional Perspective. IAFOR Journal of Education, 6(3), 63-78

31. Kim, J., Merrill, K., Xu, K., \& Sellnow, D. D. (2020). My Teacher Is a Machine: Understanding Students' Perceptions of Al Teaching Assistants in Online Education. International Journal of Human-Computer Interaction, 36(20), 1902-1911

32. Kim, W. H., \& Kim, J. H. (2020). Individualized Al Tutor Based on Developmental Learning Networks. IEEE Access, 8, 27927-27937

33. Korepin, V. N., Dorozhkin, E. M., Mikhaylova, A. V., \& Davydova, N. N. (2020). Digital Economy and Digital Logistics as New Area of Study in Higher Education. International Journal of Emerging Technologies in Learning, 15(13), 137-154

34. Liberati, A., Altman, D. G., Tetzlaff, J., Mulrow, C., Gøtzsche, P. C., loannidis, J. P. A. ... Moher, D. (2009). The PRISMA statement for reporting systematic reviews and meta-analyses of studies that evaluate health care interventions: Explanation and elaboration.PLoS Medicine, 6(7).

https://doi.org/10.1371/journal.pmed.1000100

35. Limani, Y., Hajrizi, E., Stapleton, L., \& Retkoceri, M. (2019).Peer review under responsibility of International Federation of Automatic Control.

https://doi.org/10.1016/j.ifacol.2019.12.445

Page $8 / 10$ 
36. Llorente, C. L. (2020). Robotization, Will Only Change Employment? Business and Humanism, 32(1)

37. Loftus, M., \& Madden, M. G. (2020). A pedagogy of data and Artificial Intelligence for student subjectification. Teaching in Higher Education, 25(4), 456475

38. Moridis, C. N., \& Economides, A. A. (2009). Prediction of student's mood during an online test using formula-based and neural network-based method. Computers and Education, 53(3), 644-652

39. Muniasamy, A., \& Alasiry, A. (2020). Deep Learning: The Impact on Future eLearning. International Journal of Emerging Technologies in Learning, 15(1), 188-199

40. Ocaña-Fernandez, Y., Valenzuela-Fernandez, L., \& Garro-Aburto, L. (2019). Artificial Intelligence and its Implications in Higher Education. Propósitos y Representaciones, 7(2), 536-568

41. Olusoji Ilori, M., \& Ajagunna, I. (2020). Re-imagining the future of education in the era of the fourth industrial revolution. Emerald Insight, 12(1)

42. Pana, L. (2006). Artificial Intelligence and Moral intelligence. TripleC: Communication, Capitalism. \& Critique. Open Access Journal for a Global Sustainable Information Society, 4(2), 254-264

43. Prinsloo, P. (2020). Of "black boxes" and algorithmic decision-making in (higher) education-A commentary.SAGE. https://doi.org/10.1177/2053951720933994

44. Radović, M., Petrović, N., \& Tošić, M. (2020). ONtology-based generation of multilingual questions for assessment in medical education.Journal of Teaching English for Specific and Academic Purposes,001. https://doi.org/10.22190/jtesap2001001r

45. Seers, K. (2015). Qualitative systematic reviews: their importance for our understanding of research relevant to pain.Sage. https://doi.org/10.1177/2049463714549777

46. Sekeroglu, B., Dimililer, K., \& Tuncal, K. (2019). Artificial Intelligence in Education: application in student performance evaluation. Dilemas Contemporaneos-Educacion Politica Y Valores, 7(1). \%3CGo

47. Senel, S., \& Can, S. H. (2021). Remote Assessment in Higher Education during COVID-19 Pandemic. International Journal of Assessment Tools in Education, 8(2), 181-199. https://doi.org/10.21449/ijate.820140Publishedathttps:

48. Tamla, P., Golowko, N., Boehm, T., Hemmje, M., Golowko, N., \& Stein, H. (2019). On the trail of future management topics with digital technology - how can artificial intelligence influence the didactic content of higher education in economics / Philippe Tamla / 2 updates / 1 publications / Research Project. https://www.researchgate.net/project/On-the-trail-of-future-management-topics-with-digital-technology-how-can-artificial-intelligence-influence-thedidactic-content-of-higher-education-in-economics

49. Taneri, G. (2020). Research \& Occasional Paper Series: Cshe. 6. 2020 artificial intelligence \& higher education : Towards Customized Teaching and Learning, and Skills for an Al World of Work University of California - Berkeley How the Al World is Evolving. June

50. Tashfeen, A. (2019). Scenario based approach to re-imagining future of higher education which prepares students for the future of work. Higher Education Skills and Work-Based Learning, 10(1), 217-238

51. The University of Melbourne (2021). Systematic Reviews An introduction to systematic reviews, with examples from health sciences and medicine. https://unimelb.libguides.com/c.php?g=492361\&p=3368110

52. Tsai, S. C., Chen, C. H., Shiao, Y. T., Ciou, J. S., \& Wu, T. N. (2020). Precision education with statistical learning and deep learning: a case study in Taiwan.International Journal of Educational Technology in Higher Education, 17(1). https://doi.org/10.1186/s41239-020-00186-2

53. Vinichenko, M. V., Melnichuk, A. V., \& Karácsony, P. (2020). Technologies of improving the university efficiency by using artificial intelligence: Motivational aspect. Entrepreneurship and Sustainability Issues, 7(4), 2696-2714

54. Waghid, Y., Waghid, Z., \& Waghid, F. (2019). The fourth industrial revolution reconsidered: on advancing cosmopolitan education. South African Journal of Higher Education, 33(6), 1-9

55. Williams, N. (1992). The artificial-intelligence applications to learning-program. Computers \& Education, 18(1-3), 101-107

56. Wu, W., Huang, T., \& Gong, K. (2020). Ethical Principles and Governance Technology Development of Al in China. Engineering, 6(3), 302-309

57. Xiao, M., \& Yi, H. (2020). Building an efficient artificial intelligence model for personalized training in colleges and universities.Computer Applications in Engineering Education. https://doi.org/10.1002/cae.22235

58. Xu, L., \& Yu, F. (2020). Factors that influence robot acceptance. Kexue Tongbao/Chinese Science Bulletin, 65(6), 496-510

59. Yakubu, M. N., Dasuki, S. I., Abubakar, A. M., \& Kah, M. M. O. (2020). Determinants of learning management systems adoption in Nigeria: A hybrid SEM and artificial neural network approach. Education and Information Technologies, 25(5), 3515-3539

60. Yang, C. B., Huan, S. L., \& Yang, Y. (2020). A Practical Teaching Mode for Colleges Supported by Artificial Intelligence. International Journal of Emerging Technologies in Learning, 15(17), 195-206

61. Yıldııı, B. F., \& Yıldız, M. (2018). Yapay Zeka ve Robotik Sistemlerin Kütüphanecilik Mesleğine Olan Etkileri (The Effects of Artifıcial Intelligence and Robotic Systems on Librarianship). Turk Kutuphaneciligi - Turkish Librarianship, 32(1), 26-32

62. Zapata-Ros, M. (2018). The smart university The transition from Learning Management Systems (LMS) to Smart Learning Systems (SLS) in Higher Education. Red-Revista De Educacion a Distancia, 57. https://doi.org/10.6018/red/57/10

63. Zawacki-Richter, O., Marín, V. I., Bond, M., \& Gouverneur, F. (2019). Systematic review of research on artificial intelligence applications in higher education - where are the educators? In International Journal of Educational Technology in Higher Education (Vol. 16, Issue 1). https://doi.org/10.1186/s41239019-0171-0 
Figures

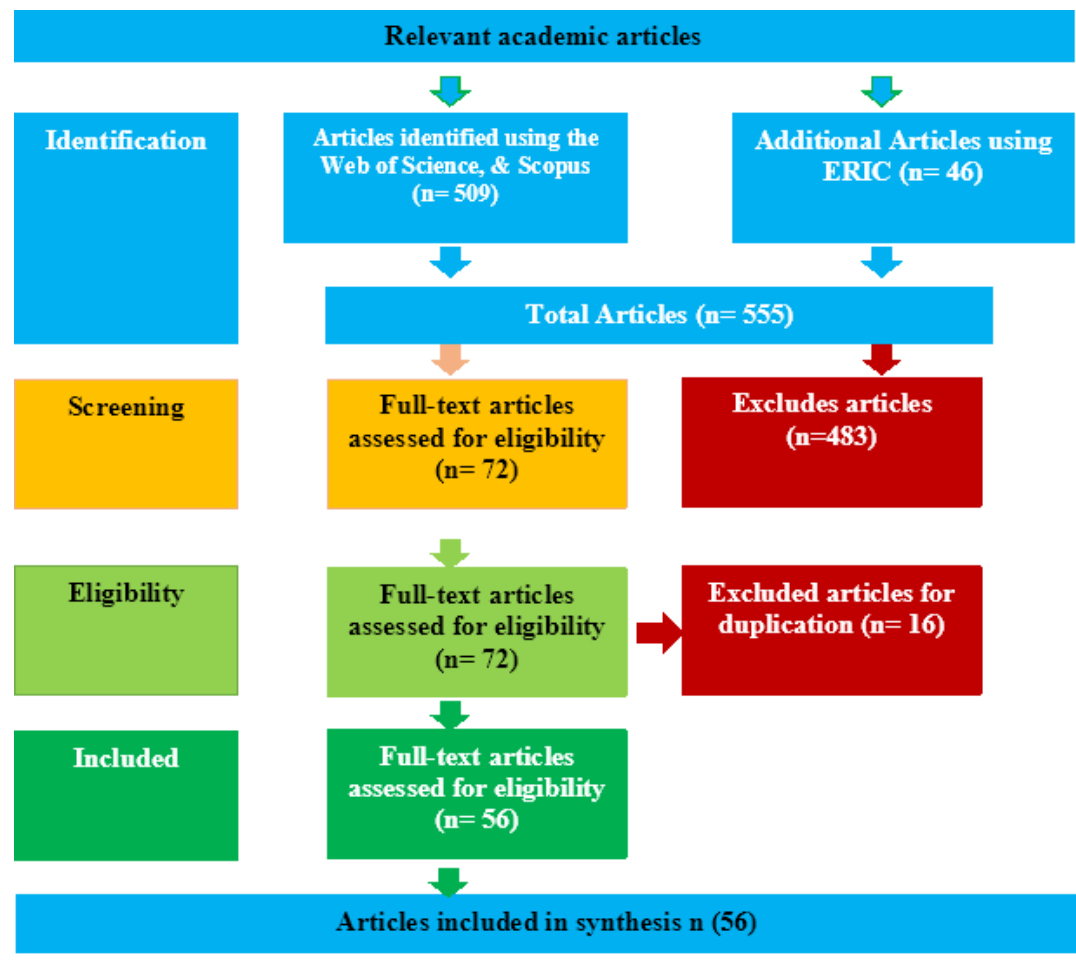

Figure 1

Inclusion and exclusion process Note: the researcher designed the figure 